\title{
Functional characterisation of the regulation of CAAT enhancer binding protein alpha by GSK-3 phosphorylation of Threonines
}

\section{2/226}

\author{
H-K Liu ${ }^{1,4}$, S Perrier ${ }^{1}$, C Lipina ${ }^{2}$, D Finlay², H McLauchlan ${ }^{3}$, CJ Hastie ${ }^{3}$, \\ HS Hundal ${ }^{1}$ and C Sutherland ${ }^{* 2}$
}

\begin{abstract}
Address: ${ }^{1}$ Division of Molecular Physiology, School of Life Sciences, University of Dundee, Dundee, DD1 4HN, UK, ${ }^{2}$ Division of Pathology and Neurosciences, Ninewells Medical School, University of Dundee, Dundee, DD1 9SY, UK, ${ }^{3}$ Division of Signal Transduction and Therapy, School of Life Sciences, University of Dundee, Dundee, DD1 4HN, UK and ${ }^{4}$ National Research Institute of Chinese Medicine, Taipei, Taiwan, Republic of China

Email: H-K Liu - hk.liu@nricm.edu.tw; S Perrier - s.perrier@dundee.ac.uk; C Lipina - c.lipina@dundee.ac.uk; D Finlay - d.finlay@dundee.ac.uk; H McLauchlan - h.j.mclauchlan@dundee.ac.uk; CJ Hastie - c.j.hastie@dundee.ac.uk; HS Hundal - h.s.hundal@dundee.ac.uk;

C Sutherland* - c.d.sutherland@dundee.ac.uk
\end{abstract}

* Corresponding author

Published: 06 April 2006

BMC Molecular Biology2006, 7:14 doi:10.1 |86/I47|-2199-7-14
Received: 09 November 2005

Accepted: 06 April 2006

This article is available from: http://www.biomedcentral.com//47/-2/99/7//4

(c) 2006Liu et al; licensee BioMed Central Ltd.

This is an Open Access article distributed under the terms of the Creative Commons Attribution License (http://creativecommons.org/licenses/by/2.0), which permits unrestricted use, distribution, and reproduction in any medium, provided the original work is properly cited.

\begin{abstract}
Background: Glycogen Synthase Kinase-3 (GSK3) activity is repressed following insulin treatment of cells. Pharmacological inhibition of GSK3 mimics the effect of insulin on Phosphoenolpyruvate Carboxykinase (PEPCK), Glucose-6 Phosphatase (G6Pase) and IGF binding protein-I (IGFBPI) gene expression. CAAT/enhancer binding protein alpha $(\mathrm{C} / \mathrm{EBP} \alpha)$ regulates these gene promoters in liver and is phosphorylated on two residues (T222/T226) by GSK3, although the functional outcome of the phosphorylation has not been established. We aimed to establish whether CEBP $\alpha$ is a link between GSK3 and these gene promoters.

Results: C/EBP $\alpha$ represses the IGFBPI thymine-rich insulin response element (TIRE), but mutation of T222 or T226 of C/EBP $\alpha$ to non-phosphorylatable alanines has no effect on C/EBP $\alpha$ activity in liver cells (towards the TIRE or a consensus C/EBP binding sequence). Phosphorylation of T222/T226 is decreased by GSK3 inhibition, suggesting GSK3 does phosphorylate T222/226 in intact cells. However, phosphorylation was not altered by treatment of liver cells with insulin. Meanwhile C/EBP $\alpha$ activity in 3T3 LI preadipocytes was enhanced by mutation of T222/T226 and/ or $\$ 230$ to alanine residues. Finally, we demonstrate that C/EBP $\alpha$ is a very poor substrate for GSK3 in vitro and in cells.

Conclusion: The work demonstrates an important role for this domain in the regulation of $\mathrm{Cl}$ EBP $\alpha$ activity in adipocytes but not hepatocytes, however GSK3 phosphorylation of these residues does not mediate regulation of this C/EBP activity. In short, we find no evidence that C/EBP $\alpha$ activity is regulated by direct phosphorylation by GSK3.
\end{abstract}




\section{Background}

Glycogen synthase kinase-3 (GSK3), an insulin-inhibited protein kinase, has been linked to the control of many cellular processes [1]. It was originally identified as the protein kinase that phosphorylated and inactivated glycogen synthase in rabbit muscle [2]. Two highly related forms of GSK3 (GSK3 $\alpha$ and GSK3 $\beta$ ) are expressed from distinct genes $[3,4]$. They share greater than $95 \%$ identity in their kinase domains and appear to be ubiquitously expressed in mammals $[3,4]$. In resting cells GSK3 activity is high and inhibition of the kinase is achieved by at least two mechanisms, firstly through phosphorylation of an N-terminal serine residue (Ser-21 in GSK3 $\alpha$, Ser-9 in GSK3 $\beta$ ) $[5,6]$, and secondly through protein protein interaction [7]. Insulin promotes the phosphorylation of Ser-9/21 of GSK3 by activation of protein kinase B (PKB, also known as c-AKT) [8], while canonical wnt signalling inhibits GSK3 independently of this N-terminal phosphorylation [9].

In liver, inhibition of GSK3 reduces expression of the Phosphoenolpyruvate Carboxykinase (PEPCK) and Glucose-6 Phosphatase (G6Pase) genes, two rate limiting enzymes in hepatic glucose production [10], as well as the IGF binding protein-1 (IGFBP1) gene [11]. These gene promoters share a related DNA sequence termed the thymine-rich insulin response element (TIRE) that plays an important role in their response to insulin [12-14]. Expression of these genes as well as GSK3 activity is abnormally high in insulin resistant states such as Type 2 diabetes mellitus (T2DM) [15-19]. Meanwhile overexpression of GSK3 antagonises insulin regulation of IGFBP1 [11]. Therefore inhibition of GSK3 is proposed as a potential target for the treatment of T2DM [1,20,21]. Indeed selective GSK3 inhibitors significantly reduce hepatic glucose output and blood glucose levels in several animal models of obesity and diabetes [22-25]. However, GSK3 is reported to have over 30 substrates, and mutation of one of these, APC, is linked to the development of colonic cancer $[20,21,26]$. In addition, genetic deletion of one of the isoforms (GSK3 $\beta$ ) leads to liver cell death, possibly due to increased sensitivity to TNF $\alpha$ [27]. Hence great care and consideration is being given to the development of GSK3 inhibitors for use in humans. With this in mind we have initiated a search for molecules that link GSK3 to the gluconeogenic gene promoters and in particular the TIRE, since inhibition of GSK3 is sufficient to repress the isolated DNA element [11]. Identification of the GSK3 substrate(s) that regulates IGFBP1, G6Pase and PEPCK gene expression, may permit manipulation of this specific interaction without affecting other GSK3 targets, thereby reducing potential side effects. GSK3 is an unusual kinase in that most substrates must be phosphorylated (primed) on a Ser/Thr four or five residues C-terminal to the GSK3 target residue (see [1] for review). Priming of the substrate is performed by a distinct protein kinase, therefore inhibition of the priming kinase indirectly inhibits GSK3 regulation of the substrate, but only those substrates primed by that particular priming kinase. Priming kinases are potential targets for more specific interference with GSK3 function.

The basic leucine zipper transcription factor, CAATenhancer binding protein alpha $(\mathrm{C} / \mathrm{EBP} \alpha)$ is a potential link between GSK3 and the gluconeogenic genes based on the following information in the literature; 1) $\mathrm{C} / \mathrm{EBP} \alpha$ is phosphorylated on two residues (T222 and T226, numbers refer to rodent sequence) by GSK3, although the functional effect of phosphorylation is not yet clear [28], 2) $\mathrm{C} / \mathrm{EBP} \alpha$ is a key molecule in the regulation of the PEPCK and G6Pase gene promoters by cAMP [29-33] and $\mathrm{T} 3$ [34], 3) C/EBP $\alpha$ is regulated by wnt [35] and insulin $[36,37]$ in brown adipocytes, and the insulin regulation involves PKB (a regulator of GSK3) [37], 4) PEPCK and G6Pase expression, as well as glucose and glycogen metabolism is abnormal in animals lacking C/EBP $\alpha$ [3840] and 5) binding of a TIRE-interacting protein is blocked using an oligonucleotide representing a known $\mathrm{C} / \mathrm{EBP} \alpha$ binding sequence [41].

Therefore, we attempted to determine whether C/EBP $\alpha$ could modulate the activity of the isolated TIRE, or the gene promoters of interest, in a GSK3 regulated manner. In addition, although T222/T226 of C/EBP $\alpha$ were identified as targets for GSK3 it has not previously been established whether S230 was a target for a 'priming' kinase, so we have also investigated whether mutation of S230 influences $\mathrm{C} / \mathrm{EBP} \alpha$ regulation.

\section{Results and discussion CIEBP $\alpha$ regulates the TIRE independently of T222/226 phosphorylation}

We have previously shown that insulin, or pharmacological inhibition of GSK3, reduced the expression of endogenous PEPCK, G6Pase and IGFBP1 genes and also the activity of the isolated thymine-rich insulin response element (TIRE) found in these gene promoters [10,11]. In an attempt to further characterise the GSK3 regulation of PEPCK, G6Pase and IGFBP1 we assessed whether a target for GSK3, namely $\mathrm{C} / \mathrm{EBP} \alpha$, could regulate TIRE activity. In the hepatocyte $\mathrm{C} / \mathrm{EBP} \alpha$ activity is linked to CAMP induction of genes, so insulin inhibition of $\mathrm{C} / \mathrm{EBP} \alpha$ could explain repression of these genes by insulin. In this model, phosphorylation of $\mathrm{C} / \mathrm{EBP} \alpha$ by GSK3 would have to induce $\mathrm{C} / \mathrm{EBP} \alpha$ activity toward the TIRE. Interestingly, $\mathrm{C} / \mathrm{EBP} \alpha$ overexpression had a repressive effect on TIRE activity in the rat hepatoma H4IIE cells (Fig 1A), and the repression was lost when the TIRE sequence was mutated at two residues to produce an insulin insensitive sequence (DM5 [42]; Fig 1A). Hence C/EBP $\alpha$ regulated the TIRE in 

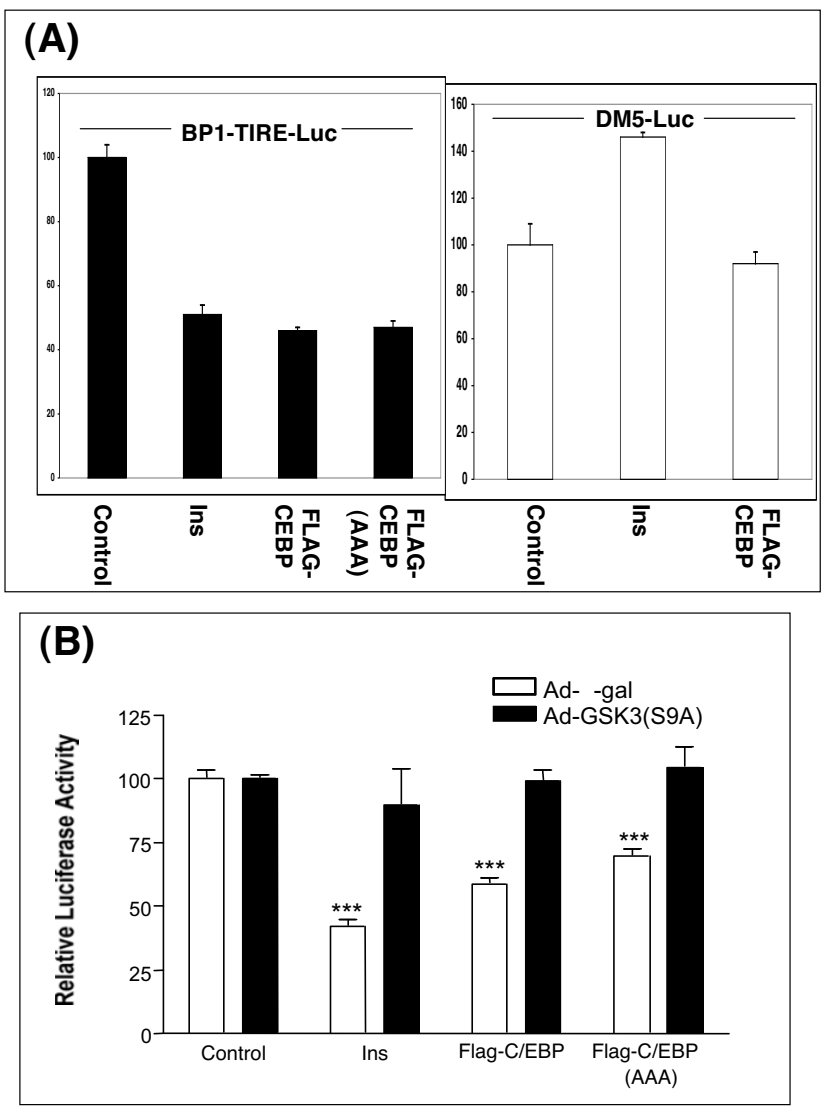

Figure I

C/EBP $\alpha$ expression suppresses the BPI-TIRE-Luc reporter activity in $\mathrm{H} 4 \mathrm{IIE}$ cells, independently of the phosphorylation status of T222/T226. (A) H4IIE cells were transfected with BPI-TIRE-Luc $(10 \mu \mathrm{g})$ or DM5-Luc ( 10 $\mu \mathrm{g})$ along with either PCDNA6 vector $(\mathrm{I} \mu \mathrm{g})$, Flag-C/EBP $\alpha(\mathrm{I}$ $\mu g)$ or Flag-C/EBP $\alpha-A A A(I \mu g)$. Subsequently, cells were incubated with or without $10 \mathrm{nM}$ insulin for $20 \mathrm{~h}$ prior to lysis and luciferase assay. Results are presented as relative luciferase activity to the control (serum free) and are average $\pm \operatorname{SEM}(n=3)$ from two independent experiments. (B) H4IIE cells were infected with adenovirus expressing either $\beta$ Galactosidase (AD- $\beta$ gal) or active GSK3 $\beta$ (Ad-GSK3 S9A) for $20 \mathrm{~h}$ prior to transfection as described in (A). Results are presented as relative luciferase activity to the control (serum free) and are average \pm SEM $(n=6)$ from two independent experiments. ${ }^{* * *} \mathrm{p}<0.00 \mathrm{I}$ compared to control (ad-b-gal).

a sequence specific and insulin-like manner. However, mutation of the GSK3-regulated residues on $\mathrm{C} / \mathrm{EBP} \alpha$ (T222/T226/S230) to alanines (C/EBP $\alpha$-AAA) did not alter the ability of $\mathrm{C} / \mathrm{EBP} \alpha$ to repress TIRE activity (Fig 1A). One possibility is that the dephosphorylated form of $\mathrm{C} / \mathrm{EBP} \alpha$ repressed the TIRE, and that the overexpressed $\mathrm{C} /$ $\mathrm{EBP} \alpha$ was not substantially phosphorylated by GSK3. Consistent with this hypothesis, co-expression of an active form of GSK3 reduced the effect of wild-type C/EBP $\alpha$ on
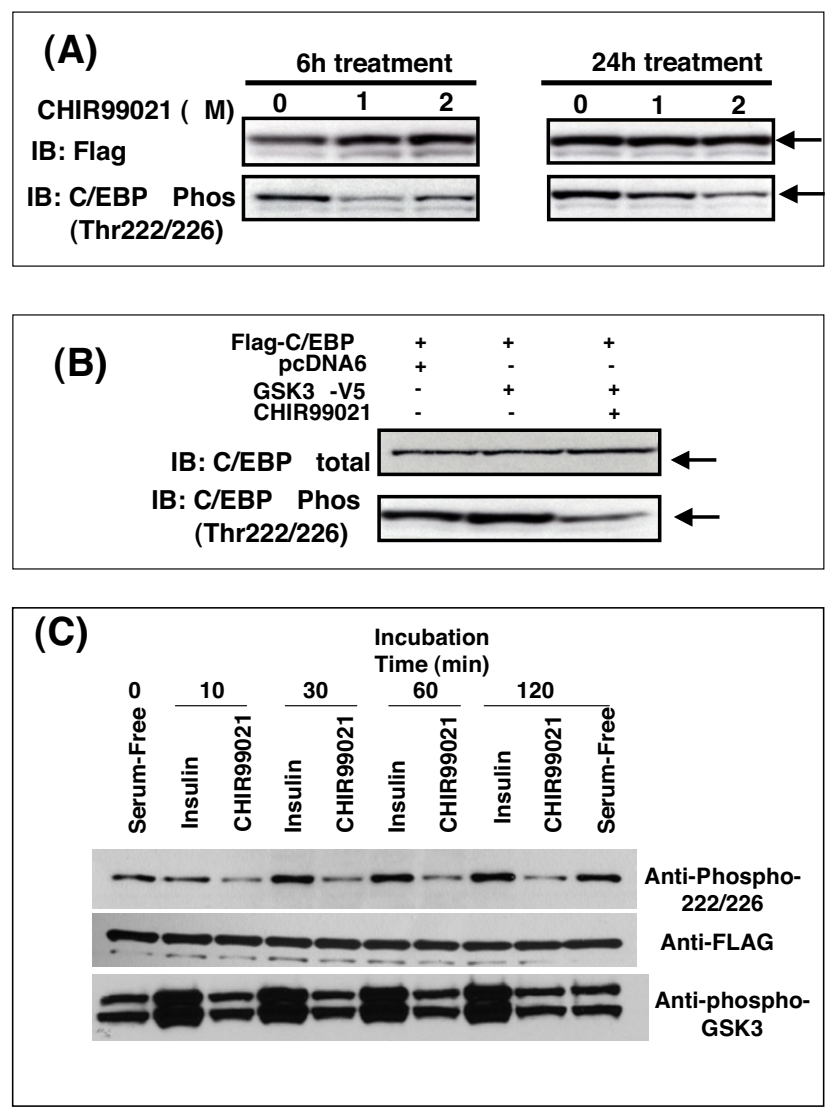

Figure 2

C/EBP $\alpha$ phosphorylation in intact cells. AD293 cells were transiently transfected with Flag-C/EBP $\alpha$ (I0 $\mu \mathrm{g})$ prior to incubation with CHIR9902I as indicated (A). Cell lysates were then subjected to Western Blotting with the antibodies as labelled. A representative immunoblot (of 2 two separate experiments) is given. (B) AD293 cells were transfected with Flag-C/EBP $\alpha(10 \mu \mathrm{g})$ plus GSK $3 \alpha-\mathrm{V} 5(10 \mu \mathrm{g})$ or pcDNA6 (I0 $\mu g)$ prior to $24 \mathrm{~h}$ incubation with CHIR9902I ( $2 \mu \mathrm{M})$, lysis and Western Blot analysis. A representative immunoblot (of three separate experiments) is given. (C) H4IIE cells were infected with adenovirus expressing Flag-C/EBP $\alpha$. After $16 \mathrm{~h}$ the infected cells were serum starved for $3 \mathrm{~h}$ prior to incubation with or without insulin (I0 nM) or CHIR9902 I (2 $\mu \mathrm{M})$ for the times indicated. Cell lysates were immunoblotted with the antibodies indicated and a representative experiment is provided.

the TIRE (Fig 1B). Unfortunately, increased GSK3 activity also blocked the repressive action of the C/EBP $\alpha$-AAA (Fig 1B) clearly demonstrating that phosphorylation of T222/ T226/S230 was not required for the action of GSK3 on the isolated TIRE in H4IIE cells. This data questioned the functional importance of T222/T226 phosphorylation in the regulation of $\mathrm{C} / \mathrm{EBP} \alpha$ activity. 


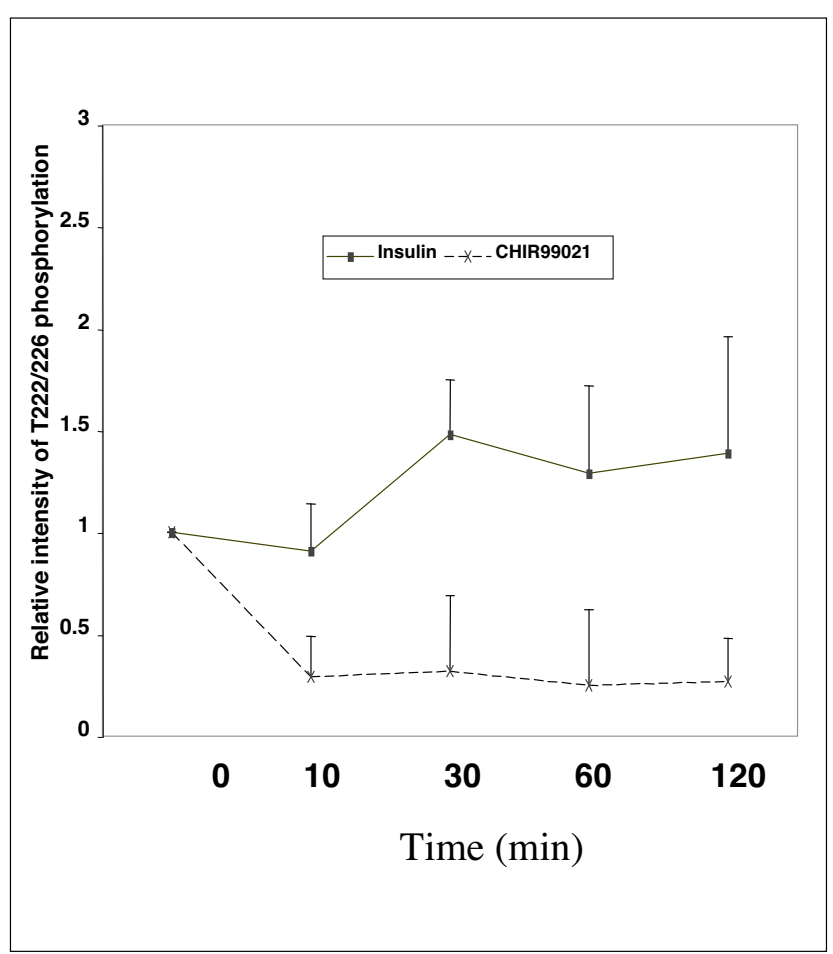

Figure 3

Quantification of three experiments performed as in Fig 2C. Results are the average \pm SEM.

\section{GSK3 phosphorylates CIEBP $\alpha$ in intact cells}

It was therefore important to establish whether T222 and T226 were actually phosphorylated by GSK3 in intact cells. Cells were transfected with wild-type and mutant C/ $\mathrm{EBP} \alpha$ and total and phosphorylated C/EBP $\alpha$ visualised by Western Blotting. T222/226 phosphorylation, measured with this antibody, was clearly present in intact cells (Fig $2)$. Incubation with 1 or $2 \mu \mathrm{M}$ of the GSK3 inhibitor CHIR99021 $[11,43]$ for 6 or 24 h significantly reduced the phosphorylation of T222/226 of wild-type C/EBP $\alpha$ (Fig 2A), confirming that GSK3 was a T222/226 kinase in these cells. At shorter incubations, $1 \mu \mathrm{M}$ CHIR99021 was sufficient to give maximal reduction in T222/226 phosphorylation, while $2 \mu \mathrm{M}$ had a greater effect at $24 \mathrm{~h}$ incubation. This is similar to the effect of these concentrations on $\beta$ catenin activation in the H4IIE cells [11]. Meanwhile, coexpression of active GSK3 $\alpha$ (Fig 2B) only produced a marginal induction of phosphorylation (around 1.2 fold) suggesting that the expressed $\mathrm{C} / \mathrm{EBP} \alpha$ was either almost fully phosphorylated at T222/226 or that it was not a particularly good substrate for GSK3. Mutation of T222/226 to alanines made the mutant $\mathrm{C} / \mathrm{EBP} \alpha$ unresponsive to the phosphospecific antibody (see later). Interestingly, the dephosphorylation of $\mathrm{C} / \mathrm{EBP} \alpha$ in H4IIE cells treated with CHIR99021 was rapid, but not complete (Fig 2C). However, there was no significant reduction in $\mathrm{T} 222 / 226$
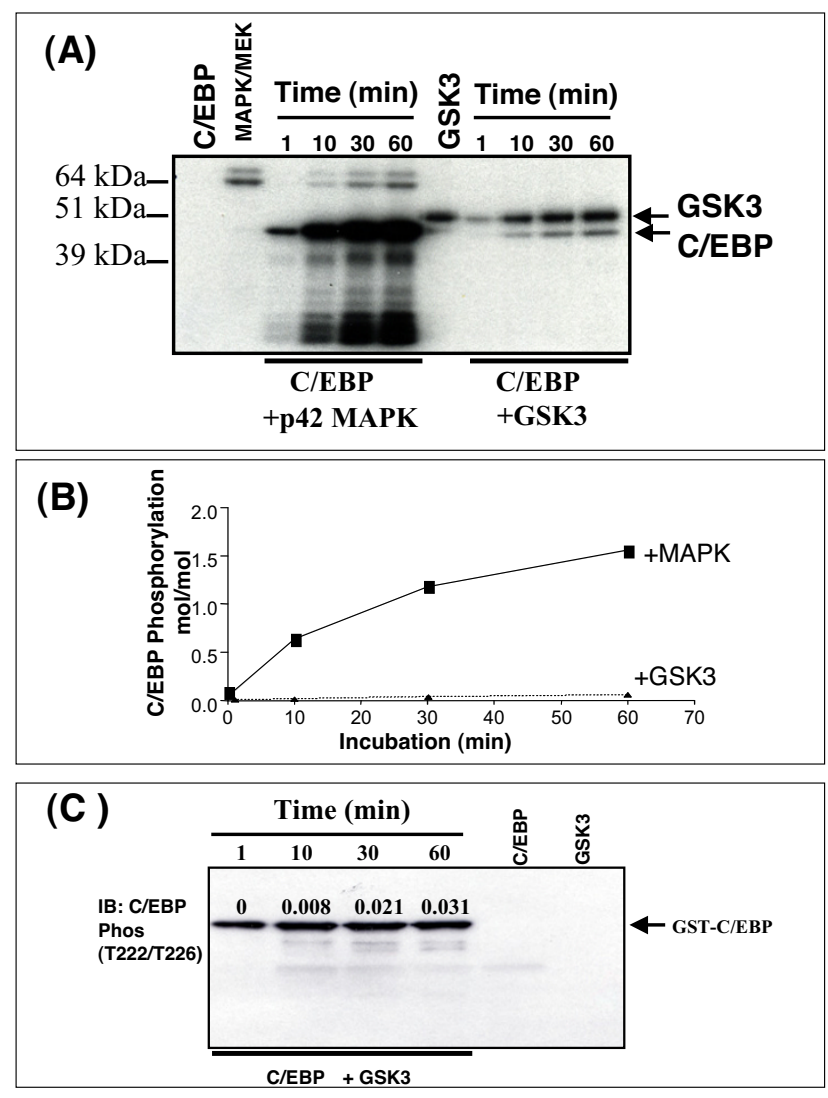

Figure 4

C/EBP $\alpha$ phosphorylation in vitro. (A) Recombinant Flag$\mathrm{C} / \mathrm{EBP} \alpha(6 \mathrm{pmol})$ was generated by scission of the GST-Cl $\mathrm{EBP} \alpha$ fusion protein and incubated with either recombinant GSK3 $\beta(2 \mathrm{U} / \mathrm{ml})$ or $\mathrm{p} 42$ MAPK $(10 \mathrm{U} / \mathrm{ml})$ and $[\gamma-32 \mathrm{P}]-A T P$ for I, 10, 30, and $60 \mathrm{~min}$. The reaction was stopped and separated by SDS-PAGE. (B) The stoichiometry of Flag-C/EBP $\alpha$ phosphorylation in $(A)$ by either MAPK or GSK3 $\beta$ is quantified and presented. (C) GST-C/EBP $\alpha$ (7.5 pmol) was incubated with recombinant GSK3 $\beta(2 \mathrm{U} / \mathrm{ml})$ and ATP for I, I0, 30 , and $60 \mathrm{~min}$. The reaction was stopped and separated by SDS-PAGE and subjected to Western Blot analysis for phospho-T222/226. The equivalent stoichiometry of phosphorylation $(\mathrm{mol} / \mathrm{mol})$ calculated in $A$ is indicated above each band.

phosphorylation following up to $2 \mathrm{~h}$ incubation with insulin (Fig 2C and Fig 3), even though insulin promoted phosphorylation of Ser9/Ser21 of GSK3 $\beta$ and GSK3 $\alpha$ respectively. Insulin reduced GSK3 activity around 50\% in the H4IIE cell line but this is clearly not sufficient to reduce T222/226 phosphorylation. Therefore it appears that insulin does not regulate T222/226 phosphorylation in these cells through inhibition of GSK3. However, the data suggested that some level of T222/226 phosphorylation by GSK3 occurs on the overexpressed protein (Fig 2C). 
Table I: Primers and oligonucleotides used in C/EBP mutagenesis. Primers and oligonucleotides

\begin{tabular}{ll}
\hline Constructs & DNA sequences \\
\hline \multirow{2}{*}{ Flag-C/EBP $\alpha$} & Forward: 5'-GGA TCC GCC ACC ATG GAC TAG AAG GAC GAC GAT GAC AAG GAG TCG GCC GAC TTC \\
& TAC GAG-3' \\
Reverse: 5'- GAA TTC TCA CGC GCA GTT GCC CAT GGC CTT GAC-3' \\
S230A Flag-C/EBP $\alpha$ mutant & Sense: 5'-CGC CCG TGC CCG CCC CTC ATC CCG-3' \\
& Antisense: 5'-CGG GAT GAG GGG CGG GCA CGG GCG-3' \\
Flag-C/EBP $\alpha$ mutant(AA) & Sense:5'-GGC CAC CCT GCG CCG CCG CCG GCG CCC GTG CCC AGC CCT CAT CCC-3' \\
& Antisense: 5'-GGG ATG AGG GCT GGG CAC GGG CGC CGG CGG CGG CGC AGG GTG GCC-3' \\
GSK3 $\alpha-V 5$ & Forward: 5'-GGA TCC GCC ACC ATG AGC GGC GGC GGG CCT T-3' \\
& Reverse: 5'-TCT AGA GGA AGA GTT AGT GAG GGT AGG TGT GGCA-3' \\
CBE-Luc reporter & Sense:5'-CGG GGT ACC CCG ATT TTT GCG CAA TTT TAT TGC GCA ATC AAT ATT GGA AGA TCT TC- 3' \\
& Antisense: 5'-GAA GAT CTT CCA ATA TTG ATT GCG CAA TAA AAT TGC GCA AAA ATC GGG GTA CCC \\
& CG-3'
\end{tabular}

\section{CIEBP $\alpha$ is a relatively poor substrate for GSK3 in vitro} We next characterised C/EBP $\alpha$ phosphorylation by GSK3 in vitro (Fig 4). Incubation of $\mathrm{C} / \mathrm{EBP} \alpha$ with $\mathrm{GSK} 3 \beta$ for up to one hour resulted in a slow incorporation of less than 0.03 mol phosphate per mol of protein (Fig 4A and 4B). In comparison, p42MAP kinase phosphorylation of $\mathrm{C} /$ EBP $\alpha$ increased over 60 min peaking around $1.5 \mathrm{~mol}$ per mol (Fig 4A and 4B). Phosphorylation of C/EBP $\alpha$ by p42MAP kinase did not occur at T222, T226 or S230 (see below) and is more likely to be on S21 [44]. Interestingly western blot analysis of $\mathrm{C} / \mathrm{EBP} \alpha$ following incubation with GSK3 $\beta$ gave little indication of this slow increase in phosphorylation, and a very strong signal was obtained with the phosphospecific antibody even at low stoichiometry of phosphorylation (Fig 4C). These data demonstrated that $\mathrm{C} / \mathrm{EBP} \alpha$ was a relatively poor substrate for GSK3 in vitro ,but that the phospho-T222/226 antibody was highly sensitive. It is difficult to directly compare phosphorylation of $\mathrm{C} / \mathrm{EBP} \alpha$ with other substrates of GSK3 as most are poorly phosphorylated prior to priming. For example CRMP phosphorylation by GSK3 (under identical conditions to those used for C/EBP $\alpha$ in Fig 4) incorporates around $0.2 \mathrm{~mol} / \mathrm{mol}$ phosphate within $2 \mathrm{~h}$ of incubation [45]. However, this increases more than 5-fold if the substrate is first primed. Of course we can never rule out the possibility that an intrinsic factor improves the GSK3-C/EBP $\alpha$ interaction in vivo, either promoting prim-

Table 2: Comparison of mouse, rat and human C/EBP $\alpha$ sequences surrounding potential GSK3 target residues. Numbers refer to mouse (upper) and human (lower) potential phosphorylated residues. C/EBP $\alpha$ sequences.

\section{0}

\section{Mouse}

Rat

Human
PGHPTPPPTPVPSPHAA

PGHPTPPPTPVPSPHPA

PGHPTPPPTPVPSPHAA

226230234 ing at an unidentified residue or allowing greater phosphorylation by GSK3.

\section{GSK3 phosphorylation of T222/226 in cells does not require $\mathbf{S 2 3 0}$ phosphorylation}

Many substrates of GSK3 are primed for kinase recognition by prior phosphorylation at a $\mathrm{S} / \mathrm{T}$ residue four amino acids C-terminal to the target site [1]. S230 lies within this 'consensus' GSK3 targeting sequence (Table 2). Therefore S230 phosphorylation could prime for T226 phosphorylation by GSK3, permitting subsequent phosphorylation of T222 by GSK3. However, mutation of S230 to alanine had no effect on T222/226 phosphorylation in intact cells (Fig 5). This argued that S230 phosphorylation did not prime for T226 phosphorylation by GSK3 in resting cells, or that the wild-type $\mathrm{C} / \mathrm{EBP} \alpha$ is not being efficiently phosphorylated at $\mathrm{S} 230$. Since the amino acid immediately following S230 is a proline (Table 2), we hypothesised that priming may only occur after induction of a prolinedirected kinase such as a member of the MAP kinase family. Therefore we attempted to induce S230 phosphorylation by incubation of cells with serum, which stimulates the classical MAP kinase and several other prolinedirected kinases such as cyclin-dependent kinases. However, T222/226 phosphorylation of wild-type or S230A C/ $\mathrm{EBP} \alpha$ was not altered in serum treated cells (Fig 5B), despite activation of the p90RSK downstream of the $\mathrm{p} 42$ / p44MAP kinase (Fig 5B). This demonstrated we could not alter S230 phosphorylation by incubating cells with or without serum. Interestingly, serum treatment induced phosphorylation of S21/9 of GSK3 $\alpha / \beta$ (Fig 5B), suggesting some inhibition of GSK3 occurs in the serum treated cells. This was not sufficient to reduce $\mathrm{C} / \mathrm{EBP} \alpha$ phosphorylation but did partially reduce glycogen synthase phosphorylation (a known substrate of GSK3 ([46]; Fig 5B). Similarly, treatment of the cells with CHIR99021 did not completely inhibit T222/226 phosphorylation (Fig 2 and Fig 3), despite a complete loss of glycogen synthase phosphorylation (Fig 5B). Therefore T222/226 must be rela- 


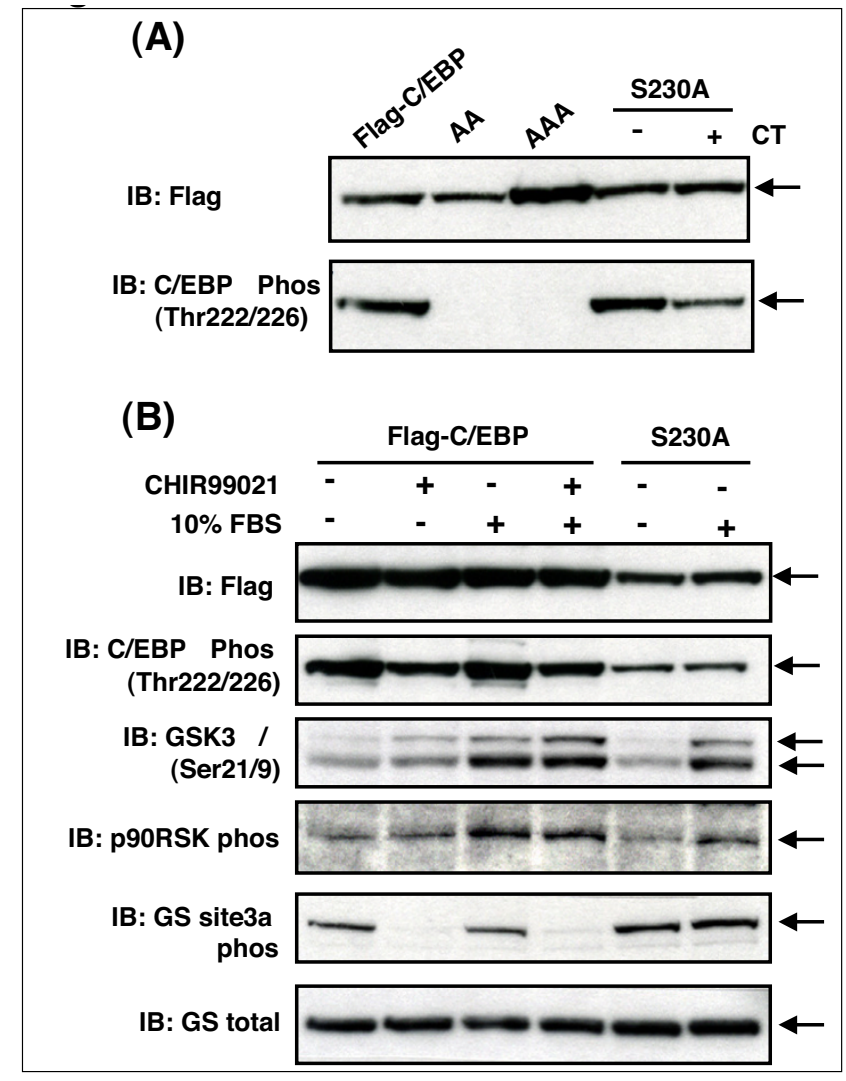

Figure 5

S230 phosphorylation does not prime for T226 phosphorylation by GSK3. (A) AD293 cells were transfected with $10 \mu \mathrm{g}$ of Flag-C/EBP $\alpha$, Flag-C/EBP $\alpha-A A$, Flag-C/EBP $\alpha-$ AAA or Flag-C/EBP $\alpha-S 230 A$ prior to $24 \mathrm{~h}$ incubation with 2 $\mu \mathrm{M}$ CHIR9902 I (CT), lysis and Western Blot analysis. A representative immunoblot of two such experiments is given.

(B) AD293 cells were transfected with $10 \mu \mathrm{g}$ of Flag-C/EBP $\alpha$ or Flag-C/EBP $\alpha-S 230 \mathrm{~A}$, then serum starved overnight prior to a $2 \mathrm{~h}$ incubation with CHIR9902I $(2 \mu \mathrm{M})$ or $10 \%(\mathrm{v} / \mathrm{v}) \mathrm{FBS}$. Cell lysates were then subjected to Western Blotting with the antibodies as labelled. A representative immunoblot of two such experiments is given.

tively resistant to dephosphorylation or a distinct T222/ 226 protein kinase must be present in these cells. Again, potential substrates for GSK3 have been reported that have their priming at a residue more distant from the GSK3 target site, and we cannot discount that possibility. However, our data strongly argues against priming through S230 phosphorylation.

Prephosphorylation of CEBP $\alpha$ by 442 MAP kinase did not prime for subsequent phosphorylation by GSK3 in vitro (Fig 6A), confirming that S230 is not targeted by p42 MAP kinase. Similarly, incubation of cells with either a p42MAP kinase inhibitor (PD98059) or a p38MAP kinase

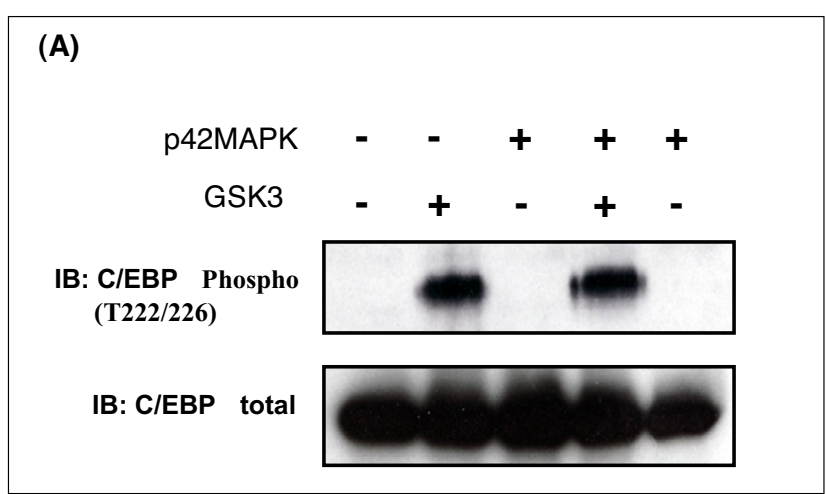

(B)

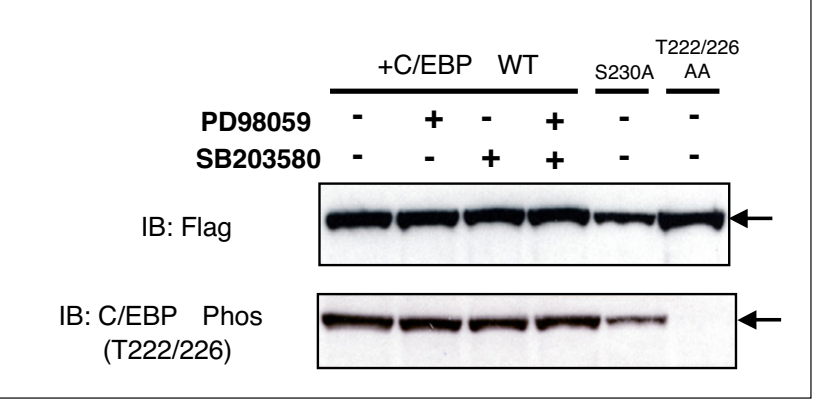

Figure 6

MAPK does not influence CEBP $\alpha$ phosphorylation by GSK3. (A) Recombinant Flag-C/EBP $\alpha$ (6 pmol) was incubated for $60 \mathrm{~min}$ with or without p42 MAPK $(10 \mathrm{U} / \mathrm{ml})$ and/ or GSK3 $\beta(2 \mathrm{U} / \mathrm{ml})$ and $\mathrm{Mg}$ ATP, as indicated in figure. The reaction was stopped and separated by SDS-PAGE and subjected to Western Blot. (B) AD293 cells were transfected with $10 \mu$ of Flag-C/EBP $\alpha$, Flag-C/EBP $\alpha-A A$, or Flag-C/ EBP $\alpha-S 230 A$ prior to $24 \mathrm{~h}$ incubation with $10 \mu \mathrm{M}$ PD98059, SB203580 or DMSO, lysis and Western Blot analysis. A representative immunoblot of two such experiments is given.

inhibitor (SB203580) had no effect on phosphorylation of CEBP $\alpha$ at T222/226 (Fig 6B).

\section{CIEBP $\alpha$ induced a consensus binding element while repressing the TIRE in H4IIE cells}

In contrast to the repressive action on TIRE activity, overexpression of $\mathrm{C} / \mathrm{EBP} \alpha$ in H4IIE cells induced the activity of a consensus C/EBP binding element (CBE) (Fig 7A). We were therefore able to investigate whether the GSK3 regulation of T222/T226 was dependent on the DNA sequence analysed. Mutation of T222/226/S230 to alanines (in any combination) made no difference to the induction of the CBE by C/EBP $\alpha$ (Fig 7A). Similarly, inhibition of GSK3 using CHIR99021 or insulin had no effect on CBE activity (Fig 7A and 7B). Therefore GSK3 phosphorylation of T222/226 does not regulate either induction of the CBE or 

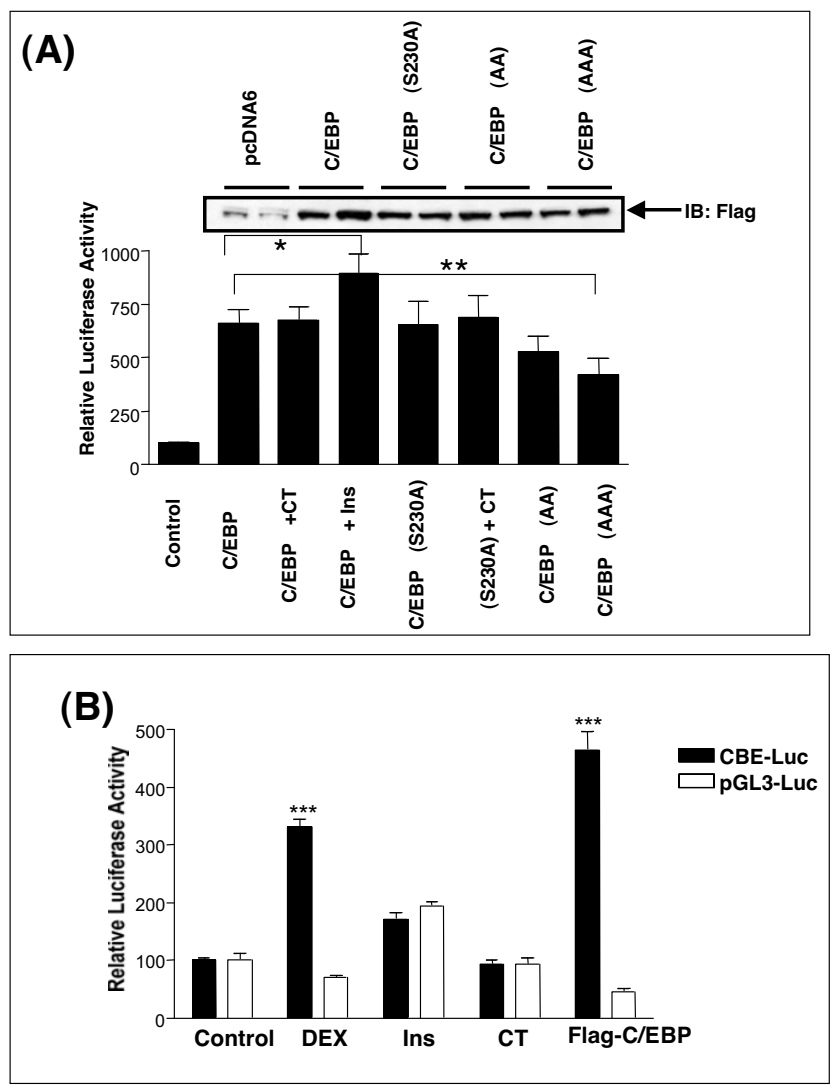

Figure 7

C/EBP $\alpha$ activity in H4IIE cells. (A) H4IIE cells were transfected with the CBE-Luc $(10 \mu \mathrm{g})$ along with I $\mu \mathrm{g}$ of PcDNA6, Flag-C/EBP $\alpha$, Flag-C/EBP $\alpha-A A$, Flag-C/EBP $\alpha-A A A$ or Flag-C/EBP $\alpha-S 230 \mathrm{~A}$ prior to a $20 \mathrm{~h}$ incubation with insulin (I0 nM) or CHIR9902I (CT, $2 \mu \mathrm{M})$. Results are presented as relative luciferase activity to control (serum free) and are average $\pm \operatorname{SEM}(n=6)$ from two independent experiments. * $p=0.0683$, ** $p=0.0523$. (B) H4IIE cells were co-transfected with $10 \mu \mathrm{g}$ of either CBE-Luc reporter or PGL3-Luc reporter plus I $\mu g$ of pcDNA6 or Flag-C/EBP $\alpha$ prior to $20 \mathrm{~h}$ incubation with dexamethasone (500 nM), insulin (I0 nM), or CHIR9902I (CT, $2 \mu \mathrm{M})$. Results are presented as relative luciferase activity to the control (serum free) and are average $\pm \operatorname{SEM}(n=6)$ from two independent experiments. ${ }^{* * *} \mathrm{p}<$ 0.001

repression of the TIRE in the H4IIE cells. Interestingly CBE activity was induced in the presence of the synthetic glucocorticoid dexamethasone to a similar level as that seen with $\mathrm{C} / \mathrm{EBP} \alpha$ overexpression (Fig 7B).

\section{CIEBP $\alpha$ overexpression does not regulate endogenous TIRE-containing genes}

In order to establish whether changes in C/EBP $\alpha$ phosphorylation could alter expression of the insulin regulated genes IGFBP1 and G6Pase, we overexpressed C/EBP $\alpha$ in H4IIE cells using an adenoviral vector to produce almost

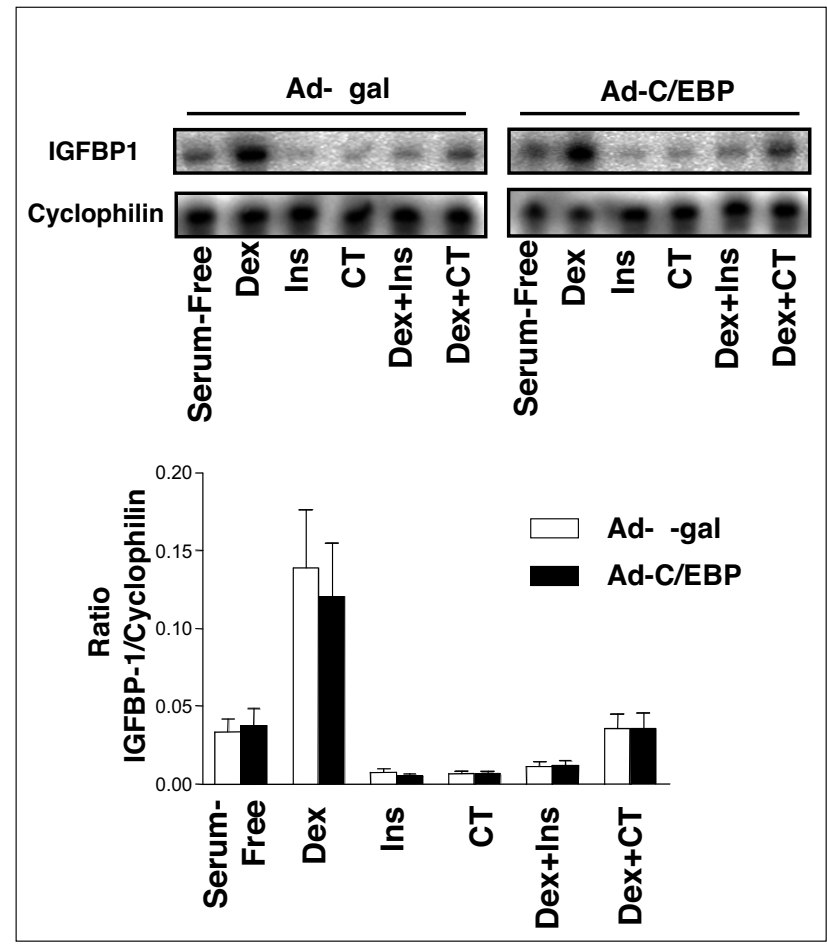

Figure 8

Regulation of endogenous IGFBP I gene expression in H4IIE cells following C/EBP $\alpha$ overexpression. H4IIE cells were infected with adenovirus expressing either $\beta$ Galactosidase (AD- $\beta$ gal) or Flag-C/EBP $\alpha$ (Ad-C/EBP $\alpha)$. Infected cells were serum starved overnight prior to a $3 \mathrm{~h}$ incubation with insulin (10 nM), dexamethasone (500 nM), CHIR9902I (CT, $2 \mu \mathrm{M})$, or a combination of each as indicated. RNA was extracted and IGFBPI expression was measured by RPA. Expression was calculated relative to cyclophilin mRNA levels. Data are presented as the average \pm SEM of three experiments, with a representative autoradiograph shown in the upper panels.

$100 \%$ transfection efficiency (Figs 8, 9, 10). We observed no effect of C/EBP $\alpha$ expression on IGFBP1 (Fig 8) or G6Pase (Fig 9) gene expression, and no alteration in regulation of either gene by dexamethasone, insulin or CHIR99021. However, there was a significant repression of the co-expressed BP1-TIRE by C/EBP $\alpha$ when compared with its effect on the insulin resistant TIRE (DM5) (Fig 10). This suggests that $\mathrm{C} / \mathrm{EBP} \alpha$ overexpression represses the isolated element but has no effect on this element when it is in the context of the intact gene promoters. This is an example of the dangers of studying isolated promoter elements and extrapolating to intact gene promoters without examining endogenous regulation. Interestingly, a postnatal knockout of $\mathrm{C} / \mathrm{EBP} \alpha$ resulted in reduced basal expression of PEPCK and G6Pase but did not alter regulation of these genes by CAMP [40]. Again, 


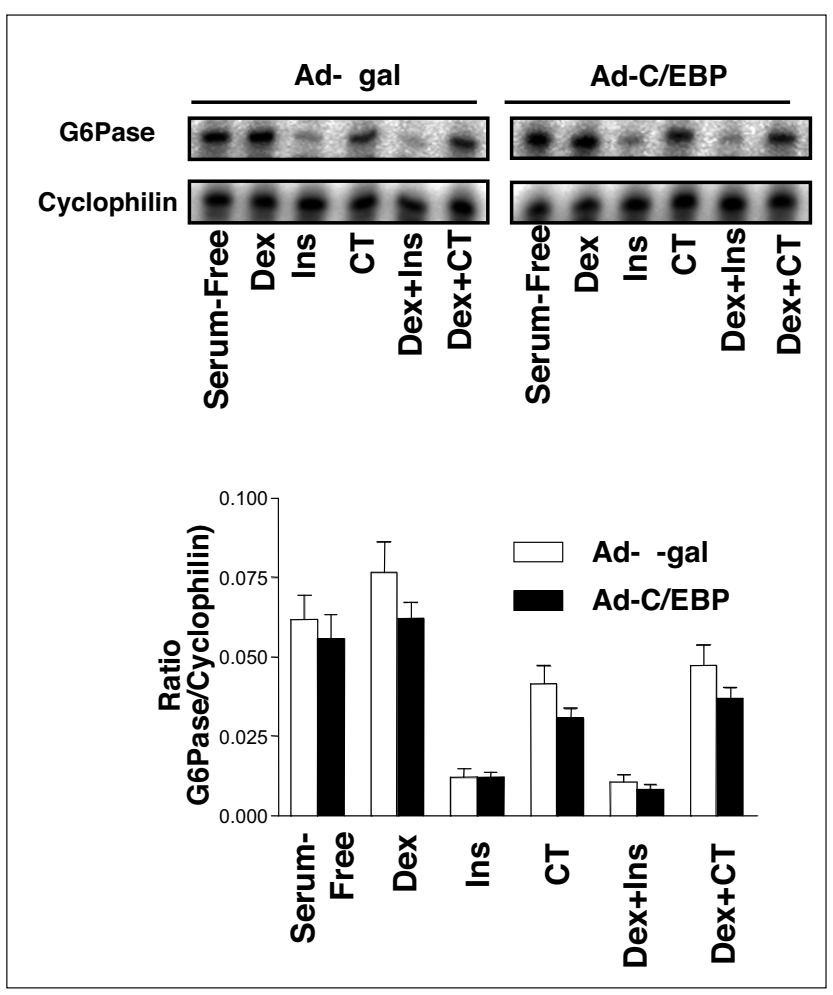

Figure 9

Regulation of endogenous G6Pase gene expression in H4IIE cells following C/EBP $\alpha$ overexpression. RNA produced as in Fig. 8 was analysed for G6Pase expression by RPA. Expression was calculated relative to cyclophilin mRNA levels. Data are presented as the average \pm SEM of three experiments, with a representative autoradiograph shown in the upper panels.

this would argue against a repressive effect of this factor on the endogenous genes.

CIEBP $\alpha$ regulation of the CBE in preadipocytes is greater when T222/226 are mutated

$\mathrm{C} / \mathrm{EBP} \alpha$ has an important role in adipocyte differentiation $[37,47,48]$, therefore we transfected 3T3-L1 preadipocytes with $\mathrm{C} / \mathrm{EBP} \alpha$ and measured $\mathrm{CBE}$ activity (Fig 11A). In contrast to the H4IIE cells, mutation of T222/226 to alanines resulted in a significant increase in transactivation potential compared to wild-type C/EBP $\alpha$ (Fig 11A). This suggested that phosphorylation of these residues was inhibiting $\mathrm{C} / \mathrm{EBP} \alpha$ activity in these cells. Consistent with this hypothesis, inhibition of GSK3 using CHIR99021 or insulin induced wild-type $\mathrm{C} / \mathrm{EBP} \alpha$ activity (Fig 11A). In addition, the C/EBP $\alpha$ S230A mutant had similar transactivation potential to the AA mutant (Fig 11A), strongly suggesting that S230 was a priming site for T222/T226 phosphorylation in these cells. However we could find no evidence that phosphorylation of T222/226 was reduced

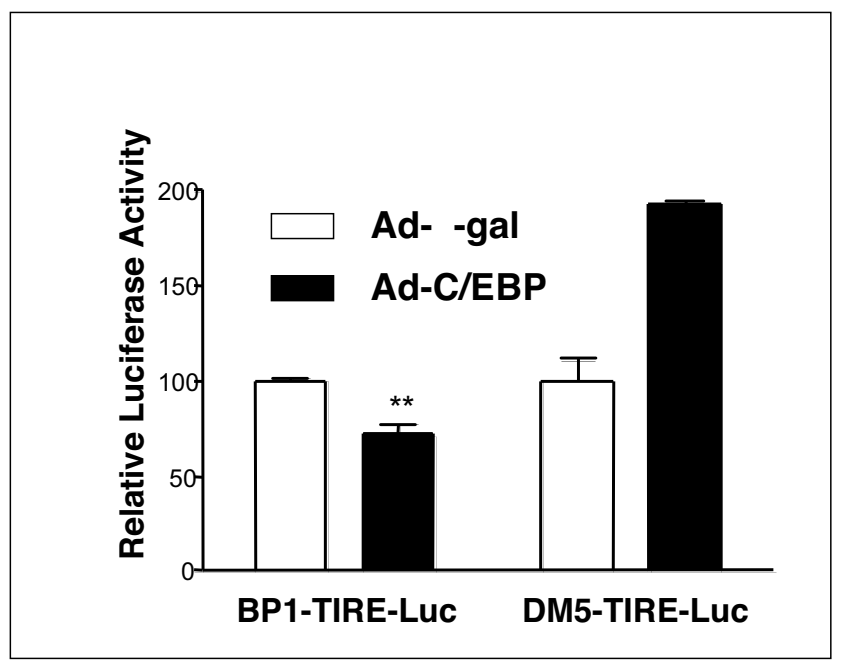

Figure 10

Regulation of the isolated TIRE in H4IIE cells following C/EBP $\alpha$ overexpression. H4IIE cells, infected as in Fig. 8 , were also transfected with $10 \mu \mathrm{g}$ of BPI-TIRE-Luc or DM5Luc and luciferase activity measured $20 \mathrm{~h}$ later. Results are presented as relative luciferase activity to the control (AD$\beta$ gal, serum free) and are average \pm SEM of three experiments. ${ }^{* *} \mathrm{p}<0.01 \mathrm{AD}-\beta$ gal versus $\mathrm{Ad}-\mathrm{C} / \mathrm{EBP} \alpha$.

in the S230A mutant (Fig 11B). Although there was a great deal of inter-experiment variation in the phosphorylation of T222/T226 in the WT and the S230A mutant there was not a significant difference between the two, and in 2 out of the three experiments the S230A mutant exhibited higher phosphorylation than the WT protein (Fig 11B). Therefore, changes in phosphorylation of these two sites cannot account for the difference in $\mathrm{C} / \mathrm{EBP} \alpha$ activity when the S230 site is mutated to alanine. Ideally it would be beneficial to confirm these data on endogenous gene expression in the adipocyte cell line, however these cells do not transfect efficiently with the adenoviral constructs making it impossible to examine their effect on endogenous genes.

\section{Conclusion}

In summary, $\mathrm{C} / \mathrm{EBP} \alpha$ is not the link between GSK3 and the hepatic TIRE-containing gene promoters. However, C/ $\mathrm{EBP} \alpha$ can regulate the TIRE, at least when overexpressed, and the residues T222/226 and S230 all influence C/EBP $\alpha$ function in preadipocytes. Interestingly we demonstrate opposite effects of $\mathrm{C} / \mathrm{EBP} \alpha$ overexpression on TIRE and CBE activity, and a tissue specific role for the T222/226 motif in this activity. Our data also provides further evidence of the differences in transcription factor activity when measured using isolated promoter elements as opposed to intact gene promoters. During the course of this study a regulation of C/EBP $\beta$ by GSK3 in adipocytes 

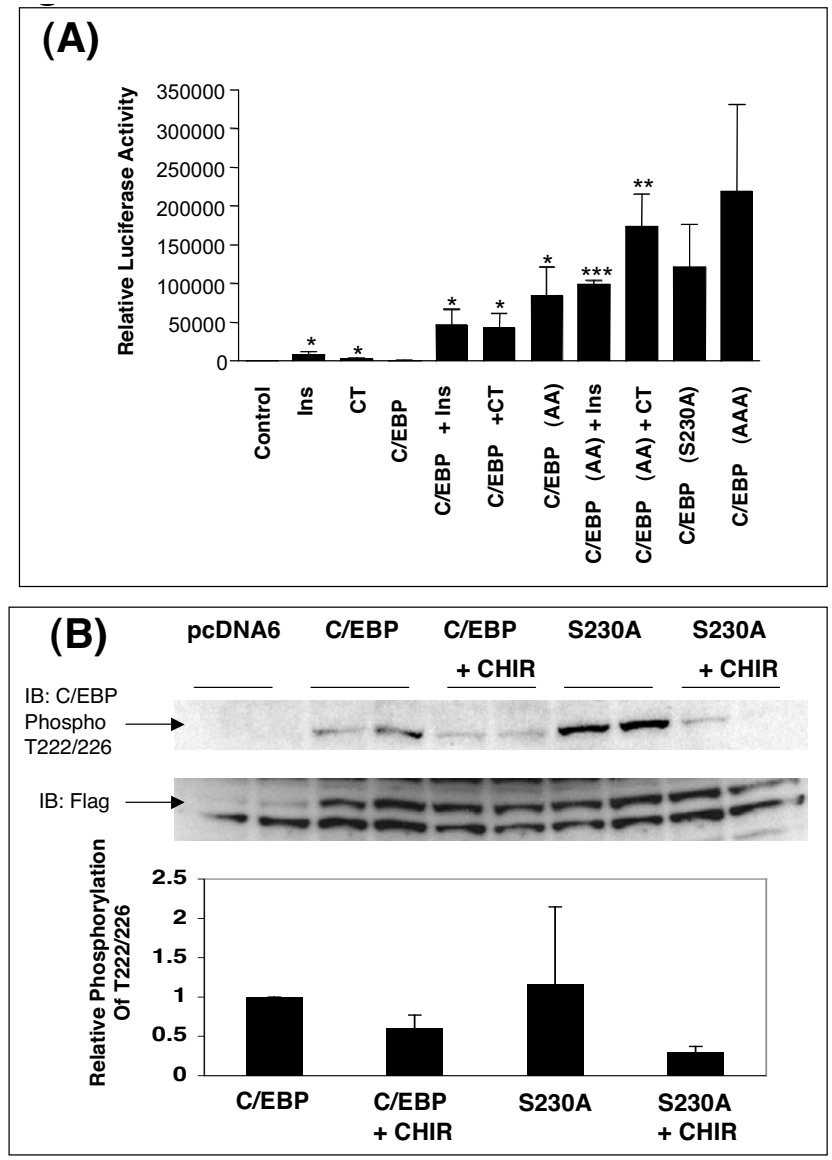

Figure I I

Mutation of T222/226 and S230 alters C/EBP $\alpha$ activity in preadipocytes. A) $3 \mathrm{~T} 3 \mathrm{LI}$ preadipocytes were transfected with $2 \mu \mathrm{g}$ of C/EBP-Luc reporter along with $200 \mathrm{ng}$ of pcDNA6, Flag-C/EBP $\alpha, A A, A A A$, or S230A as described in the material and methods. Cells were incubated with insulin (100 nM) or CHIR9902I (CT, I0 $\mu$ M) for $20 \mathrm{hr}$ prior to harvest for luciferase assay. Results are relative luciferase activity and are average \pm SEM $(n=6)$ from two independent experiments. ${ }^{*} p<0.05$, ** $p<0.01$, *** $p<0.005$ compared with control. B) 3T3LI preadipocytes were transfected with 200 ng of pcDNA6, Flag-C/EBP $\alpha$ wild type, or Flag-C/EBP $\alpha$ S230A, $\pm 2 \mu \mathrm{M}$ CHIR9902 I (CT). Cells were lysed, the recombinant protein immunoprecipitated using anti-FLAG, and visualised using anti-FLAG or anti-phospho222/226. A representative experiment is shown in the upper panel, while a quantification of three such experiments is given in the lower panel.

was reported [49]. Therefore it will be of interest to confirm whether this C/EBP isoform is the link between GSK3 inhibition and TIRE regulation in hepatocytes.

\section{Methods}

Material

Radioisotopes $\left[\gamma^{32} \mathrm{P}\right] \mathrm{ATP}$ (Amersham Biosciences, Inc., Little Chalfont, Buckinghamshire, UK) and [ $\alpha$-32P]UTP (ICN, Thame, Oxfordshire, UK) were purchased from the indicated sources. Insulin was obtained from Novo Nordisk (Crawley, West Sussex, UK), dexamethasone and IBMX (Sigma, Poole, Dorset, UK), RNAse Protection Assay Kit II was from AMS Biotech/Ambion (Austin, TX, USA). CHIR99021 was synthesised by Dr Rudolpho Marquez [11]. Antibodies to the following epitopes were purchased from the companies in parenthesis; C/EBP $\alpha$ (Santa Cruz Biotechnologies, UK), phospho-C/EBP $\alpha$ (T222/226) and phospho-GSK3 $\alpha / \beta$ (S21/9) (Cell Signaling Technologies, Hertfordshire, UK), Flag (Sigma, Poole, Dorset, UK), while the Glycogen Synthase (total and site 3 phospho antibody), and p90 RSK phospho antibody were made in the Division of Signal Transduction Therapy, University of Dundee.

\section{Cell culture}

The rat hepatoma cell line H4IIE was cultured in Dulbecco's Modified Eagle's Medium (DMEM) containing $1000 \mathrm{mg} / \mathrm{L}$ glucose, 5\% (v/v) foetal calf serum (GIBCO, Carlsbad, CA). The AD293 cell line was maintained in DMEM containing $4500 \mathrm{mg} / \mathrm{L}$ glucose, 10\% (v/v) foetal calf serum, while 3T3-L1 preadipocytes were grown in DMEM containing $4500 \mathrm{mg} / \mathrm{L}$ glucose and 10\% (v/v) newborn calf serum (GIBCO).

\section{Construction of plasmid DNA, luciferase reporter, and mutagenesis}

The full length $\mathrm{C} / \mathrm{EBP} \alpha \mathrm{cDNA}$ was amplified by PCR from a rat $\mathrm{L} 6$ cDNA library and BamHI/Kosac/Flag and EcoRl sequences introduced at the $5^{\prime}$ and 3 ' end respectively as indicated in Table 1 . The PCR product was subcloned into TOPO one shot (Invitrogen), verified by DNA sequencing, and subcloned into pcDNA6, GST-pGEX-6, and pshuttle$\mathrm{CMV}$ vectors for the purpose of expression in mammalian cells, production of recombinant GST-tagged protein in Escherichia coli BL21 cells, and construction of recombinant adenovirus (AdEasy XL Adenoviral Vector System, Stratagene), respectively. Flag-C/EBP $\alpha$ point mutants, S230A, T222A/T226A (AA), and T222A/T226A/S230A (AAA) were generated using the QuickChange mutagenesis kit (Stratagene) with the oligo sequences shown in Table 1. The AAA mutant was generated by introducing the S230A point mutation into the AA mutant. A luciferase reporter construct containing a C/EBP consensus binding sequence (CBE-Luc) 5' of a thymidine kinase promoter was constructed using the oligos shown in Table 1. Both sense and antisense oligos were annealed prior to restriction digest with Kpnl and Bgl II. The product was subcloned into the BP1 luciferase reporter linearised with Kpnl and BamHI to remove the TIRE (the luciferase con- 
struct was a gift from Dr Robert Hall and Professor Daryl K. Granner (Vanderbilt University, TN, USA)).

\section{Transient transfection}

AD293 cells were transiently transfected with $10 \mu \mathrm{g}$ of pcDNA6, Flag-C/EBP $\alpha$, AA, AAA, or S230A mutants by the calcium phosphate method. DNA precipitant was added to cells for $4 \mathrm{~h}$, prior to addition of inhibitors and hormones at the concentrations and for the times indicated in figure legends.

H4IIE cells were transfected as described previously [50]. Briefly, $10 \mu \mathrm{g}$ of BP1-TIRE-Luc, the insulin insensitive point mutant of the TIRE (DM5-Luc), C/EBP-Luc, or pGL3-Luc (control), along with $1 \mu \mathrm{g}$ of pcDNA6, wild type or mutant Flag-C/EBP $\alpha$ constructs were precipitated and incubated with H4IIE cells in suspension. Cells were plated onto $10 \mathrm{~cm}$ dishes, allowed to attach for $4 \mathrm{~h}$, prior to DMSO shock and incubation with hormones/inhibitors for $20 \mathrm{~h}$ as indicated in figure legends. Cells were lysed in $200 \mu \mathrm{l}$ lysis buffer (Promega, UK), the cell debris removed by centrifugation at $13,000 \times \mathrm{g}$ for $10 \mathrm{~min}$ at $4^{\circ} \mathrm{C}$, and the supernatant stored at $-70^{\circ} \mathrm{C}$. Luciferase assays were performed using the firefly luciferase assay system (Promega, UK), according to manufacturer's instructions, with luciferase activity being corrected for the protein concentration in the cell lysate.

3T3-L1 preadipocytes were transfected using Fugene 6 Transfection Reagent (Roche) following manufacture's protocol. C/EBP-Luc $(2 \mu \mathrm{g})$ along with $200 \mathrm{ng}$ of pcDNA6, wild type or mutant Flag- $\mathrm{C} / \mathrm{EBP} \alpha$ constructs was complexed with Fugene 6 transfection reagent prediluted in Serum Free DMEM at the ratio of 1:3 ( $\mu$ g DNA : $\mu$ l Fugene 6 ) for $20 \mathrm{~min}$ at RT before addition to cells. After $4 \mathrm{~h}$ at $37^{\circ} \mathrm{C}$ an equal amount of DMEM containing $20 \%$ foetal calf serum was added. $48 \mathrm{~h}$ post-transfection, cells were washed with serum free DMEM and incubated for a further $24 \mathrm{~h}$ in serum free media with or without hormones or inhibitors as described in figure legends. Cells were lysed in $100 \mu \mathrm{l}$ lysis buffer and luciferase activity determined as above.

We estimate that the level of over expression of C/EBP $\alpha$ is roughly 4 fold in the adipocytes, around 6-fold in the liver cells by transient transfection and nearly 10 fold in adenovirally infected H4IIE experiments

\section{In vitro phosphorylation of CIEBP $\alpha$}

Purified recombinant $\mathrm{C} / \mathrm{EBP} \alpha(6 \mathrm{pmol})$ was incubated at $30^{\circ} \mathrm{C}$ with $\mathrm{His}_{6}$-GSK3 $\beta(2 \mathrm{U} / \mathrm{ml})$ or p42 MAPK $(10 \mathrm{U} / \mathrm{ml})$, $10 \mathrm{mM}$ magnesium acetate, $0.1 \mathrm{mM}\left[\gamma_{-}\right.$-32P]ATP $(450,000$ $\mathrm{cpm} / \mathrm{nmol}$ ) in buffer containing $50 \mathrm{mM}$ Tris-HCl, $\mathrm{pH} 7.5$, $0.03 \%(\mathrm{v} / \mathrm{v})$ Brij 35, and 0.1\% (v/v) 2-mercaptoethanol, for times indicated in the figure legends. Reactions were stopped by the addition of LDS containing sample buffer (Novex), heated at $70^{\circ} \mathrm{C}$ for $10 \mathrm{~min}$ and subjected to SDSPAGE. The gel was dried on the $3 \mathrm{M}$ Filterpaper, and radioactivity incorporated into recombinant $\mathrm{C} / \mathrm{EBP} \alpha$ visualized by autoradiography and quantified by phosphorimager (Fuji). A standard curve of radiolabelled ATP was used to assess nmoles of phosphate incorporated into the $\mathrm{C} / \mathrm{EBP} \alpha$ substrate. p42 MAP kinase and GSK3 activities were calculated by in vitro phosphorylation of myelin basic protein and P-GS peptide, respectively.

\section{Preparation of cell extract for SDS PAGE and Immunoblotting}

Cells were washed with ice cold PBS twice and scraped into ice-cold lysis buffer (25 mM Tris/HCl, pH 7.4, $50 \mathrm{mM}$ $\mathrm{NaF}, 100 \mathrm{mM} \mathrm{NaCl}, 1 \mathrm{mM}$ sodium vanadate, $5 \mathrm{mM}$ EGTA, $1 \mathrm{mM}$ EDTA, 1\% (v/v) Triton X-100, $10 \mathrm{mM}$ sodium pyrophosphate, $1 \mathrm{mM}$ benzamidine, $0.1 \mathrm{mM}$ PMSF, $0.27 \mathrm{M}$ sucrose, $2 \mu \mathrm{M}$ microcystin and $0.1 \%$ (v/v) 2-mercaptoethanol). Cell debris was removed by centrifugation at $13,000 \times \mathrm{g}$ for $10 \mathrm{~min}$ at $4^{\circ} \mathrm{C}$. Preparation of nuclear protein extracts was performed using a Nuclear Extraction Kit (Panomics), as per the manufacture's instructions. The protein concentration was determined by Bradford assay (Sigma), using BSA as standard as per the manufacture's instructions. Protein from cell lines (10-20 $\mu \mathrm{g}$ from H4IIE, $50 \mu \mathrm{g}$ from AD293 or 3T3 preadipocytes) was separated on Novex SDS 4-12\% polyacrylamide gels. Following transfer to nitrocellulose, blots were blocked with $5 \%$ $(\mathrm{w} / \mathrm{v})$ non-fat milk in TBST (Tris-buffered saline containing $0.1 \%(\mathrm{v} / \mathrm{v})$ Tween 20$)$ for $1 \mathrm{~h}$, and incubated with primary antibodies at $4^{\circ} \mathrm{C}$ overnight prior to incubation for $1 \mathrm{~h}$ at RT with the secondary antibody and development using ECL kit (Amersham Biosciences, Inc.).

\section{Adenoviral Infection, RNA extraction and RNAse protection assay}

For RNA studies, H4IIE cells were infected with recombinant adenovirus expressing Flag-C/EBP $\alpha$ (Ad-C/EBP $\alpha$ ) or $\beta$-Galactosidase (Ad- $\beta$-gal) for $4 \mathrm{~h}$ at $\mathrm{MOI}=50.24 \mathrm{~h}$ later, infected cells were split into $10 \mathrm{~cm}$ dishes and serum starved overnight prior to treatment with hormone/inhibitor for $3 \mathrm{~h}$ at the concentrations indicated in the figure legends. Total cellular RNA was isolated using TRI Reagent (Sigma) following the manufacturer's instructions. An RNase Protection Assay (RPA) was performed to determine the relative amounts of IGFBP-1, G6Pase, and cyclophilin mRNA as described previously [50]. Band intensity was quantified on a phosphorimager (Fuji), data calculated as a ratio of IGFBP-1 to cyclophilin mRNA. For phosphorylation studies, H4IIE cells were infected with recombinant adenovirus expressing Flag-C/EBP $\alpha$ (Ad-C/ $\mathrm{EBP} \alpha)$ at $\mathrm{MOI}=100.16 \mathrm{~h}$ later, infected cells were serum starved for $3 \mathrm{~h}$ prior to treatment with hormone/inhibitor 
for the times and at the concentrations indicated in the figure legends.

\section{Statistics}

The comparison of one variable between two groups was determined by unpaired Student's t-test with the aid of PRISM 3.0 (Graphpad Software, USA) and/or Microsoft Excel. The values were expressed as mean \pm S.E.M.

\section{Abbreviations}

PEPCK; Phosphoenolpyruvate Carboxykinase, IGFBP1; IGF binding protein-1, G6Pase; glucose-6-phosphatase, RPA; RNAse Protection Assay, TIRE; thymine rich insulin response element, C/EBP; CAAT enhancer binding protein, $\mathrm{CBE}$; C/EBP binding element.

\section{Authors' contributions}

The majority of the molecular work was performed by HKL, with important contributions from SP (adipocyte analysis, and phosphorylation time course), CL (endogenous gene transcription), and DF (adenoviral synthesis and production). Key reagents were produced to high quality by JH and HM. The project was conceived and jointly supervised by HSH and CS.

\section{Acknowledgements}

$C L$ is a recipient of a BBSRC CASE studentship while CS is a recipient of the Diabetes UK Senior Fellowship (BDA:RD02/0002473). This work was primarily supported by Diabetes UK grant (BDA:RD03/0002583).

\section{References}

I. Frame S, Cohen P: GSK3 takes centre stage more than 20 years after its discovery. Biochem / 200I, 359:I-I6.

2. Embi N, Rylatt DB, Cohen P: Glycogen Synthase Kinase-3 from Rabbit Skeletal Muscle. Eur J Biochem 1980, 107(2):519-527.

3. Woodgett JR: Molecular cloning and expression of glycogen synthase kinase- 3/factor A. EMBO J 1990, 9(8):243।-2438.

4. Woodgett JR: cDNA cloning and properties of GSK3. Meth Enzymol I99I, 200:564-577.

5. Sutherland $C$, Leighton IA, Cohen P: Inactivation of glycogen synthase kinase- $3 \beta$ by phosphorylation; new kinase connections in insulin and growth factor signalling. Biochem J 1993, 296: $15-19$

6. Sutherland $C$, Cohen P: The $\alpha$-isoform of glycogen synthase kinase-3 from rabbit skeletal muscle is inactivated by p70 66 kinase or MAP kinase- activated protein kinase- $I$ in vitro. FEES Lett 1994, 338:37-42.

7. Farr GH, Ferkey DM, Yost C, Pierce SB, Weaver CD, Kimelman D: Interaction among GSK-3, GBP, axin, and APC in Xenopus axis specification. J Cell Biol 2000, I 48:69|-702.

8. Cross DAE, Alessi DR, Cohen P, Andjelkovich M, Hemmings BA: Inhibition of GSK3 by insulin mediated by protein kinase $B$. Nature 1995, 378:785-789.

9. Arias AM, Brown AM, Brennan K: Wnt signalling: pathway or network? Curr Opin Genet Dev 1999, 9:447-454.

10. Lochhead PA, Coghlan MP, Rice SQJ, Sutherland C: Inhibition of GSK3 selectively reduces G6Pase and PEPCK gene expression. Diabetes 200I, 50:937-947.

II. Finlay D, Patel S, Dickson LM, Shpiro N, Marquez R, Rhodes CJ, Sutherland C: Glycogen Synthase Kinase-3 Regulates IGFBP-I Gene Transcription Through the Thymine-rich Insulin Response Element: Inhibition is required for full regulation of this promoter element by insulin. BMC Mol Biol 2004, 5:15.

12. O'Brien RM, Lucas PC, Forest CD, Magnuson MA, Granner DK: Identification of a sequence in the PEPCK gene that medi- ates a negative effect of insulin on transcription. Science 1990 , 249:533-537.

13. Suwanichkul A, Allander SV, Morris SL, Powell DR: Glucocorticoids and insulin regulate expression of the human gene for IGFBP-I through proximal promoter elements. J Biol Chem 1994, 269(49):30835-30841.

14. Ayala JE, Streeper RS, Desgrosellier JS, Durham SK, Suwanichkul A, Svitek CA, Goldman JK, Barr FG, Powell DR, O'Brien RM: Conservation of an insulin response unit between mouse and human glucose-6-phosphatase catalytic subunit gene promoters: transcription factor FKHR binds the insulin response sequence. Diabetes 1999, 48(9): I885-1889.

15. Brismar K, Gutniak M, Povoa G, Werner S, Hall K: Insulin regulates the $35 \mathrm{kDa}$ IGF binding protein in patients with diabetes mellitus. J Endocrinol Invest 1988, I I (8):599-602.

16. Luo JM, Murphy LJ: Differential expression of insulin-like growth factor-I and insulin-like growth factor binding protein-I in the diabetic rat. Mol Cell Biochem 1991, 103(1):4I-50.

17. Barzilai N, Rossetti L: Role of glucokinase and glucose-6-phosphatase in the acute and chronic regulation of hepatic glucose fluxes by insulin. J Biol Chem 1993, 268(33):25019-25023.

18. Hofmann C, Lorenz K, Williams D, Palazuk BJ, Colca JR: Insulin sensitization in diabetic rat liver by an antihyperglycemic agent. Metabolism 1995, 44:384-389.

19. Nikoulina SE, Ciaraldi TP, Mudaliar S, Mohideen P, Carter L, Henry RR: Potential role of GSK-3 in skeletal muscle insulin resistance of type 2 diabetes. Diabetes 2000, 49:263-27I.

20. Meijer L, Flajolet M, Greengard P: Pharmacological inhibitors of GSK-3. TIPS 2004, 25(9):47।-480.

21. Cohen P, Goedert M: GSK-3 Inhibitors: Development and Therapeutic Potential. Nat Rev Drug Discovery 2004, 3:479-487.

22. Cline GW, Johnson K, Regittnig W, Perret P, Tozzo E, Xiao L, Damico C, Shulman GI: Effects of a novel GSK3 inhibitor on insulin stimulated glucose metabolism in ZDF (fa/fa) rats. Diabetes 2002, $51: 2903-2910$.

23. Henriksen EJ, Kinnick TR, Teachey MK, O'Keefe MP, Ring D, Johnson KW, Harrison SD: Modulation of Muscle Insulin Resistance by Selective Inhibition of Glycogen Synthase Kinase-3 in Zucker Diabetic Fatty Rats. Am J Physiol Endocrinol Metab 2003, 285(I):E98-EI05.

24. Ring DB, Johnson KW, Henriksen EJ, Nuss JM, Goff D, Kinnick TR, Ma ST, Reeder JW, Samuels I, Slabiak T, et al.: Selective GSK-3 inhibitors potentiate insulin activation of glucose transport and utilization in vitro and in vivo. Diabetes 2003, 52(3):588-595.

25. Dokken BB, Sloniger JA, Henriksen E): Acute selective glycogen synthase kinase-3 inhibition enhances insulin signaling in prediabetic insulin-resistant rat skeletal muscle. Am J Physiol Endocrinol Metab 2005, 288(6):EI I88-EI I 94.

26. Hart MJ, de los Santos R, Albert IN, Rubinfeld B, Polakis P: Downregulation of b-catenin by human axin and its association with the APC tumour suppressor, b-catenin and GSK3b. Curr Biol 1998, 8:573-58I.

27. Hoeflich KP, Luo J, Rubie EA, Tsao M-S, Jin O, Woodgett JR: Requirement for GSK3beta in cell surival and NFkB activation. Nature 2000, 406:86-90.

28. Ross SE, Erickson RL, Hemati N, MacDougald OA: Glycogen synthase kinase 3 is an insulin-regulated C/EBPalpha kinase. Mol Cell Biol 1999, I 9(12):8433-844I.

29. Roesler WJ, Crosson SM, Vinson C, McFie PJ: The alpha-isoform of the CCAAT/enhancer-binding protein is required for mediating CAMP responsiveness of the phosphoenolpyruvate carboxykinase promoter in hepatoma cells. J Biol Chem 1996, 27 I(14):8068-8074.

30. Croniger C, Trus M, Lysek-Stupp K, Cohen H, Liu Y, Darlington GJ, Poli V, Hanson RW, Reshef $L$ : Role of the isoforms of CCAATI enhancer-binding protein in the initiation of phosphoenolpyruvate carboxykinase (GTP) gene transcription at birth. J Biol Chem 1997, 272(42):26306-263I2.

31. Yeagley D, Agati JM, Quinn PG: A tripartite array of transcription factor binding sites mediates CAMP induction of phosphoenolpyruvate carboxykinase gene transcription and its inhibition by insulin. J Biol Chem 1998, 273(30): 18743-18750.

32. Crosson SM, Roesler WJ: Hormonal regulation of the phosphoenolpyruvate carboxykinase gene. Role of specific CCAAT/enhancer-binding protein isoforms. J Biol Chem 2000, 275(8):5804-5809. 
33. Routes JM, Colton LA, Ryan S, Klemm D): CREB (cAMP response element binding protein) and C/EBPalpha (CCAAT/ enhancer binding protein) are required for the superstimulation of phosphoenolpyruvate carboxykinase gene transcription by adcnoviral Ela and cAMP. Biochem J 2000, 352(Pt 2):335-342.

34. Jurado LA, Song S, Roesler WJ, Park EA: Conserved amino acids within CCAAT enhancer-binding proteins (CTEBP(alpha) and beta) regulate phosphoenolpyruvate carboxykinase (PEPCK) gene expression. J Biol Chem 2002, 277(3 I):27606-276I2.

35. Kang S, Bajnok L, Longo KA, Petersen RK, Hansen JB, Kristiansen K, MacDougald OA: Effects of Wnt signaling on brown adipocyte differentiation and metabolism mediated by PGC-Ialpha. Mol Cell Biol 2005, 25(4): I272-I 282.

36. MacDougald OA, Cornelius $P$, Liu R, Lane MD: Insulin regulates transcription of the CCAAT/enhancer binding protein $(C /$ EBP) alpha, beta, and delta genes in fully-differentiated 3T3LI adipocytes. J Biol Chem 1995, 270(2):647-654.

37. Valverde AM, Arribas M, Mur C, Navarro P, Pons S, Cassard-Doulcier $A M$, Kahn CR, Benito M: Insulin-induced up-regulated uncoupling protein-I expression is mediated by insulin receptor substrate I through the phosphatidylinositol 3-kinase/Akt signaling pathway in fetal brown adipocytes. J Biol Chem 2003, 278(12): $|022|-1023 \mid$.

38. Wang ND, Finegold MJ, Bradley A, Ou CN, Abdelsayed SV, Wilde MD, Taylor LR, Wilson DR, Darlington GJ: Impaired energy homeostasis in C/EBP alpha knockout mice. Science 1995, 269(5227): I I08-IIII.

39. Lee YH, Sauer B, Johnson PF, Gonzalez FJ: Disruption of the clebp alpha gene in adult mouse liver. Mol Cell Biol 1997 , I 7(10):60|4-6022.

40. Yang J, Croniger CM, Lekstrom-Himes J, Zhang P, Fenyus M, Tenen DG, Darlington G], Hanson RW: Metabolic response of mice to a postnatal ablation of CCAAT/enhancer-binding protein alpha (C/EBPalpha). J Biol Chem 2005. M503486200

41. Unterman T, Oehler D, Ngyuen H, Sengupta P, Lacson R: A novel DNA/protcin complex interacts with the insulin-like growth factor binding protein-I (IGFBP-I) insulin response sequence and is required for maximal effects of insulin and glucocorticoids on promoter function. Prog Growth Factor Res 1995, 6(2-4): 119-129.

42. Hall RK, Yamasaki T, Kucera T, Waltner-Law M, O'Brien RM, Grainier DK: Regulation of Phosphoenolpyruvate Carboxykinase and Insulin-like Growth Factor-binding Protein-I Gene Expression by Insulin. THE ROLE OF WINGED HELIX/ FORKHEAD PROTEINS. J Biol Chem 2000, 275:30169-30I75.

43. Murray JT, Campbell DG, Morrice N, Auld GC, Shpiro N, Marquez R, Peggie M, Bain J, Bloomberg GB, Grahammer F, et al: Exploitation of KESTREL to identify NDRG family members as physiological substrates for SGKI and GSK3. Biochem / 2004 384(3):477-488.

44. Ross SE, Radomska HS, Wu B, Zhang P, Winnay JN, Bajnok L, Wright WS, Schaufele F, Tenen DG, MacDougald OA: Phosphorylation of C/EBPalpha inhibits granulopoiesis. Mol Cell Biol 2004, 24(2):675-686.

45. Cole A, Knebel A, Morrice NA, Robertson LS, Irving AJ, Connolly CN, Sutherland C: GSK-3 phosphorylation of the Alzheimers epitope within collapsin response mediator proteins regulates axon elongation in primary neurons. J Biol Chem 2004, 279(48):50I76-50।80.

46. MacAulay K, Hajduch E, Blair AS, Coghlan MP, Smith SA, Hundal HS: Use of lithium and SB-4I 5286 to explore the role of glycogen synthase kinase-3 in the regulation of glucose transport and glycogen synthase. Eur J Biochem 2003, 270( I 8):3829-3838.

47. Darlington GJ, Ross SE, MacDougald OA: The role of C/EBP genes in adipocyte differentiation. I Biol Chem 1998 273(46):30057-30060.

48. Park BH, Qiang L, Farmer SR: Phosphorylation of C/EBPbeta at a consensus extracellular signal-regulated kinase/glycogen synthase kinase 3 site is required for the induction of adiponectin gene expression during the differentiation of mouse fibroblasts into adipocytes. Mol Cell Biol 2004, 24(19):867I-8680.

49. Tang QQ, Gronborg M, Huang H, Kim JW, Otto TC, Pandey A, Lane $M D$ : Sequential phosphorylation of CCAAT enhancer-bind- ing protein beta by MAPK and glycogen synthase kinase 3beta is required for adipogenesis. Proc Natl Acad Sci USA 2005, I02(28):9766-977I.

50. Patel S, Lochhead PA, Rena G, Fumagalli S, Pende M, Kozma S, Thomas GM, Sutherland C: Insulin regulation of IGF-binding protein-I gene expression is dependent on mammalian target of rapamycin (mTOR), but independent of S6K activity. I Biol Chem 2002, 277(12):9889-9895.
Publish with Biomed Central and every scientist can read your work free of charge

"BioMed Central will be the most significant development for disseminating the results of biomedical research in our lifetime. "

Sir Paul Nurse, Cancer Research UK

Your research papers will be:

- available free of charge to the entire biomedical community

- peer reviewed and published immediately upon acceptance

- cited in PubMed and archived on PubMed Central

- yours - you keep the copyright

Submit your manuscript here:

http://www.biomedcentral.com/info/publishing_adv.asp
BioMedcentral 